\title{
BEBERAPA MIKROORGANISME YANG MENGHASILKAN ENZIM INULINASE, ISOLASI DAN KARAKTERISASI ENZIM DARI Aspergillus flavus Gmn11.2 GALUR LOKAL
}

\author{
Saryono $^{1}$, Fitriani ${ }^{2}$, R. Ukun M.S. Soedjanaatmadja ${ }^{2, *}$ \\ ${ }^{1}$ Jurusan Kimia, Fakultas Matematika dan Ilmu Pengetahuan Alam, Universitas Riau, Kampus Bina Widya \\ Pekanbaru, 28293, Indonesia \\ ${ }^{2}$ Departemen Kimia, Fakultas Matematika dan Ilmu Pengetahuan Alam, Universitas Padjadjaran, Jln. Raya \\ Bandung-Sumedang km. 21 Jatinangor, Sumedang, Jawa Barat 45363 \\ *Alamat Korespondensi: ukun@unpad.ac.id
}

\begin{abstract}
Abstrak: Indonesia merupakan negara tropis yang kaya akan berbagai tumbuhan dan mikroorganisme. Beberapa mikroorganisme memiliki kemampuan untuk menghasilkan enzim inulinase yang sangat bermanfaat untuk industri pangan dan farmasi. Inulinase adalah enzim yang menghidrolisis inulin menjadi fruktosa atau frukto-oligosakarida. Untuk mengisolasi inulinase dalam jumlah yang cukup banyak dari tumbuhan cukup sulit, oleh sebab itu inulinase mikrobial merupakan obyek penelitian yang sangat menarik bagi para peneliti. Tujuan penelitian ini adalah isolasi dan indentifikasi berbagai jenis jamur lokal yang potensial menghasilkan inulinase, serta isolasi dan pemurnian inulinase dari A. flavus Gmn11.2 galur lokal. Mikroorganisme A. flavus Gmn11.2 galur lokal dikembangbiakan pada media fermentasi skala labu $250 \mathrm{~mL}$, yang mengandung induser inulin selama 84 jam pada suhu $37^{\circ} \mathrm{C}$. Enzim inulin (ekstraselular) yang diproduksi selanjutnya diisolasi dan dimurnikan melalui tahapan fraksionasi amonium sulfat pada rentang kejenuhan 40-80\%, kromatografi kolom filtrasi Gel Sephadex G-25 $(100 \times 2 \mathrm{~cm})$, kromatografi kolom penukar ion DEAE selulosa $(20 \times 1,6 \mathrm{~cm})$, dengan elusi gradien 0,01-0,1 M buffer natrium fosfat pada laju alir $3 \mathrm{~mL} / \mathrm{menit}$. Enzim murni hasil isolasi kemudian ditentukan kondisi optimum aktivitas serta parameter kinetikanya. Hasil Penelitian menunjukkan bahwa dari berbagai mikroorganisme yang memiliki potensi untuk menghasilkan enzim inulinase dengan aktivitas yang tinggi adalah Aspergillus clavatus (BG5), Fusarium solani (PB3), Fusarium sp2 (LB2), dan A. flavus (ML2). Setelah melalui tahapan kromatografi penukar ion, diperoleh enzim inulinase yang cukup murni yang ditandai dengan intensitas pita hasil SDS elektroforesis, dengan peningkatan faktor kemurnian 15,66 kali dibandingkan dengan ekstrak enzim kasar. Adapun aktivitas enzim inulinase hasil isolasi dari A. flavus Gmn11.2 galur lokal, bekerja pada kondisi optimum: $\mathrm{pH} 5,0$, suhu $50^{\circ} \mathrm{C}$ dan waktu inkubasi 4 jam. Parameter kinetika enzimatik dari inulinase diperoleh harga $\mathrm{K}_{\mathrm{M}} 33 \mathrm{mg} / \mathrm{L}$ dan $\mathrm{V}_{\text {maks }} 1,8 \times 10^{-3} \mu \mathrm{mol} / \mathrm{menit}$. Dari hasil elektroforesis SDS poliakrilamida menunjukkan enzim inulinase dari A. flavus Gmn11.2 galur lokal, memiliki berat molekul (Mr) $138 \mathrm{kDa}$, terdiri dari dua sub-unit polipeptida (dimer) dengan $\mathrm{Mr}$ masing-masing 72 dan 66 $\mathrm{kDa}$.
\end{abstract}

Kata kunci: Inuliase, frukto-oligosakarida, A. flavus Gmn11.3, A. clavatus, Fusarium sp2

Abstract: Indonesia is a tropical country rich in the variety of plants and microorganisms. Some microorganisms have the ability to produce the inulinase enzyme which is very beneficial to food and pharmaceutical industry. Inulinase enzyme hydrolyzes inulin to form fructose or fructo-oligosaccharide. It is difficult to isolate the inulinase in large quantitiy from plants. Therefore, microbial inulinase is a very interesting research objects for researchers. The purpose of this research were to isolate and identify various types of local potential inulinase producing fungus, as well as the isolation and purification of inulinase from A. flavus Gmn11.2 local strain. A. flavus Gmn11.2 local strain was cultured in $250 \mathrm{~mL}$ fermentation media, containing inulin for 84 hours at $37^{\circ} \mathrm{C}$. The extracellular enzyme produced was then isolated and purified through ammonium sulfate fractionation using 40-80\% saturation range, followed by gel filtration on Sephadex G-25 $(100 \times 2 \mathrm{~cm})$ and DEAE cellulose ion exchange $(20 \times 1.6 \mathrm{~cm})$ column chromatography with 0.01-0.1 M sodium phosphate buffer elution gradient and $3 \mathrm{~mL} / \mathrm{min}$ flow rate. Later on, optimum condition for pure enzyme activity and the kinetic parameters was determined. The results showed that among various microorganisms, the microorganism that has potential ability for producing inulinase with high activity were A. clavatus (BG5), Fusarium solani (PB3), Fusarium sp2 (LB2), and A. flavus (ML2). After going through purification stages, fairly pure inulinase was obtained and characterized by SDS electrophoresis. Increased purity of 15.66 fold compared to the rough extract of the enzyme was observed. The enzyme showed optimum work in the following condition: $\mathrm{pH}$ 5.0, $50^{\circ} \mathrm{C}$ temperature, and 4 hours incubation time. The kinetics parameters of inulinase obtained the values of $K_{M} 33 \mathrm{mg} / \mathrm{L}$ and $V_{\text {maks }} 1.8 \times 10^{-3} \mu \mathrm{mol} / \mathrm{min}$. SDS-Polyacrylamide Gel Electrophoresis result showed that the inulinase of A. flavus Gmn11.2 local strain has molecular weight (Mr) of $138 \mathrm{kDa}$, consists of two sub-units of polypeptide (dimer) with 72 and $66 \mathrm{kDa} M \mathrm{Mr}$ of each units, respectively.

Keywords: Inulinase, fructo-oligosaccharide, A. flavus Gmn11.3, A.clavatus, Fusarium sp2 


\section{PENDAHULUAN}

Studi tentang enzim mikrobial dan aplikasi biokatalisnya merupakan pengembangan bioteknologi mikroba yang penting dimasa depan. Reaksi enzimatik sangat menguntungkan karena dapat berlangsung dalam kondisi yang ringan (mild). Aplikasi reaksi enzimatik dapat dikelompokkan kedalam tiga bagian utama yaitu: untuk sintesis senyawa yang bermanfaat, reaksi biokonversi dan untuk hidrolisis senyawa polimer yang menghasilkan monomer penting (Smith 1997).

Inulinase adalah enzim yang menghidrolisis inulin menjadi fruktosa atau frukto-oligosakarida.Enzim ini dapat dihasilkan oleh beberapa jenis tumbuhan maupun mikroorganisme.Untuk mengisolasi inulinase dalam jumlah yang cukup dari tumbuhan, cukup sulit. Oleh sebab itu, kajian mengenai inulinase mikrobial sangat menarik dan menjadi perhatian banyak peneliti (Kaur et al. 1992).

Enzim-enzim mikrobial banyak digunakan di hampir setiap bidang industri, lebih sering digunakan dibandingkan dengan penggunaan enzim-enzim yang berasal dari hewan atau tanaman. Hal itu disebabkan karena aktivitas yang lebih tinggi, tidak menghasilkan produk samping, lebih stabil dan murah serta dapat diperoleh dalam jumlah yang lebih banyak (Kiran et al. 2006). Kebanyakan enzim yang akhir-akhir ini digunakan dalam industri makanan dan farmasi adalah enzim mikrobial dan pemanfaatan mikroorganisme untuk memproduksi enzim semakin lebih intensif (Kango \& Jain 2011).

Produksi fruktosa dari inulin menggunakan inulinase memerlukan satu tahapan reaksi saja dengan rendemen $95 \%$, sedangkan produksi fruktosa dari pati memerlukan tiga tahap reaksi enzimatis dengan rendemen $\pm 45 \%$ (Workman \& Day 1983; Gupta et al. 1990). Hidrolisis inulin secara kimiawi memerlukan biaya tinggi dan menghasilkan senyawa difruktosa anhidrat yang rasanya pahit (Fleming \& Grootwassink 1979).

Untuk mendapatkan inulinase mikrobial yang memiliki potensi industri, enzim ini perlu dimurnikan terlebih dahulu sebelum mempelajari sifat-sifat kinetikanya. Inulinase dari mikroba pertama kali diisolasi dari Saccharomyces fragilis tahun 1960 (Allais et al. 1987; Guiraud \& Galzi 1990). Produksi enzim ini umumnya diinduksi oleh inulin, yang merupakan substrat inulinase (Burne et al. 1999; Gupta et al. 1992). Aktivitas inulinase banyak ditemukan pada spesies jamur antara lain: Aspergillus niger, Kluyveromyces marxianus, Saccharomyces cerevisiae (Viswanathan \& Kulkarni 1995; Cruzguerrero et al. 1995) dan beberapa spesies bakteri seperti Arthrobacter ureafaciens; Bacillus stearothermophilus dan lain-lain (Allais et al. 1986; Belmari et al. 1994; Chung et al. 1996; Baron et al. 1996). Dari beberapa temuan tadi, ternyata belum dilaporkan adanya strain yang benar-benar unggul sebagai penghasil inulinase, sehingga aplikasi enzim ini pada skala industri belum dilakukan. Akan hal penggunaan inulinase untuk makanan telah terdaftar pada "Food and Drug Administration" (FDA) tahun 1995 (Prosky \& Hoebregs 1999).

Umbi dahlia yang mengandung inulin sebanyak 69-75\% memiliki prospek untuk diolah menjadi High Fructose Syrup (HFS) atau Frukto-oligosakarida. Menurut Vandamme \& Derycke (1983), sampel tanah dan umbi tanaman penghasil inulin seperti umbi dahlia yang telah busuk merupakan sumber mikroba penghasil inulinase. Hasil penelitian sebelumnya memperlihatkan bahwa sejumlah jamur yang diisolasi dari daerah Padang Panjang (Sumbar) memiliki aktivitas inulinase. Oleh sebab itu perlu diteliti spesies-spesies jamur lokal penghasil inulinase yang produktif, dalam rangka mencari galur yang unggul. Selain itu perlu diteliti pula apakah inulinase dari jamur galur lokal memiliki sifat-sifat yang sama dengan inulinase yang telah ditemukan olah peneliti sebelumnya.

Penelitian ini penting terutama untuk menemukan inulinase yang memiliki aktivitas dan spesifisitas yang tinggi. Enzim ini kemudian dapat digunakan untuk memproduksi pemanis alternatif dari inulin umbi dahlia. Langkah ini sejalan dengan penelitian Lembaga Internasional, Regional maupun organisasi perdagangan dan perbankan, yang menyimpulkan bahwa dalam jangka panjang akan terjadi kekurangan gula yang kritis. Inulin dapat dipakai sebagai induser untuk menghasilkan inulinase oleh jamur seperti: $A$. niger, $K$. marxianus dan lain lain. Namun ekspresi ini dapat pula dihambat oleh adanya fruktosa di dalam media. Akan tetapi, ada juga induser yang bukan merupakan substrat yang dapat menginduksi sintesis enzim. Penambahan gliserol ke dalam media, terbukti dapat meningkatkan produksi dan aktivitas enzim inulinase oleh $K$. marxianus. Penambahan senyawa induktif pada konsentrasi yang tepat akan membawa hasil nyata untuk produksi enzim terinduksi tersebut (Suhartono 1989; Viswanathan \& Kulkarni 1995; Cruzquerrero et al. 1995). Fruktan adalah nama umum yang digunakan untuk karbohidrat yang memiliki satu atau lebih ikatan fruktosa-fruktosa seperti pada inulin dan fruktooligosakarida. Senyawa ini dalam sistem pencernaan memiliki efek fisiologi yang sistemik pada absorpsi mineral, metabolisme karbohidrat dan lipid, keseimbangan hormon, dan keseimbangan nitrogen. Selain itu fruktan juga dapat mengurangi penyakit sembelit, infeksi diare, kanker, keropos tulang, atherosklerosis, penyakit jantung, kegemukan dan diabetes yang tidak tergantung insulin (Roberfroid \& Dezenne 1998; Levi \& Werman 1998).

Pada penelitian ini, yang dilakukan adalah proses skrining berbagai isolat mikroorganisme yang berasal dari beberapa sentra perkebunan dahlia yang memiliki potensi menghasilkan enzim inulinase. Salah satu isolat jamur yaitu A. flavus, yang diidentifikasi ternyata dapat mensintesis enzim inulinase (EC.3.2.1.7.) dengan aktivitas yang cukup tinggi, yang diproduksi dalam medium yang 
mengandung umbi dahlia (Jerusalem artichoke) sebagai sumber inulin. Isolat jamur A. flavus Gmn11.2 galur lokal ini, selanjutnya digunakan sebagai sumber enzim inulinase untuk diisolasi, dimurnikan dan dikarakterisasi dengan menentukan kondisi optimum dan parameter kinetikanya.

\section{BAHAN DAN METODE}

\section{Isolasi dan Identifikasi Jamur Penghasil Inulinase}

Isolat jamur penghasil enzim inulinase diperoleh dari beberapa isolat jamur dari umbi dahlia yang berasal dari perkebunan Brastagi (Kode BG), Pekanbaru (PB), Batu Raden (BR) dan Malang (ML).

\section{Media Isolasi Jamur}

Media untuk isolasi jamur digunakan PDA (Potato Dextrose Agar). Sebanyak 200 g kentang yang telah dikupas, diiris dan direbus dengan aquades selama 20 menit, filtratnya dijadikan volume $1 \mathrm{~L}$, kemudian ditambahkan $20 \mathrm{~g}$ dekstrosa. Media padat dibuat dengan menambahkan $20 \mathrm{~g}$ agar bacto, kemudian disterilisasi pada suhu $120^{\circ} \mathrm{C}$ selama 15 menit.

\section{Media Fermentasi untuk Sub-kultur dan Produksi Inulinase}

Komposisi media sub-kultur dan media produksi terdiri dari: inulin umbi dahlia $2 \%$, yeast extract $0,5 \%$, magnesium sulfat $0,05 \%$, fero sulfat $0,015 \%$, natrium klorida $0,2 \%$ dan kalium klorida $0,05 \%$.

\section{Proses Fermentasi dan Pembuatan Kurva Pertumbuhan}

Jamur A. flavus Gmn11.2 galur lokal dibiakan dalam media agar miring dengan masa inkubasi 2 hari pada suhu $30^{\circ} \mathrm{C}$. Sebanyak dua mata ose spora dari biakan jamur pada agar miring diinokulasikan ke dalam $25 \mathrm{~mL}$ media sub-kultur dan diinkubasi selama 24 jam dalam shakerbath pada suhu $30^{\circ} \mathrm{C}$. Kemudian media sub-kultur dimasukkan ke dalam $250 \mathrm{~mL}$ media fermentasi. Proses fermentasi dilakukan selama 7 hari dan ditentukan kurva pertumbuhannya. Setiap 12 jam diambil contoh sebanyak $10 \mathrm{~mL}$ untuk ditentukan populasi jamur, aktivitas inulinase dan kadar proteinnya. Untuk menentukan populasi jamur, miselia jamur dikeringkan dalam oven pada suhu $80^{\circ} \mathrm{C}$ dan ditentukan berat keringnya. Enzim inulinase diisolasi dari medium (filtrat) fermentasinya (Ertan et al. 2005).

\section{Produksi, Isolasi dan Penentuan Aktivitas Inulinase}

Jamur A. flavus Gmn11.2 dibiakkan dalam media agar miring inulin dengan masa inkubasi 2 hari dalam shaker-bath pada suhu $30^{\circ} \mathrm{C}$. Kemudian sebanyak enam mata ose diinokulasikan ke dalam $75 \mathrm{~mL}$ media sub-kultur dan diinkubasi selama 24 jam dalam shaker-bath pada suhu $30^{\circ} \mathrm{C}$. Media fermentasi disentrifugasi pada kecepatan $25.000 \mathrm{~g}$ selama 30 menit pada suhu $4^{\circ} \mathrm{C}$. Supernatan yang dihasilkan bersisi enzim kasar yang akan dimurnikan. Aktivitas enzim inulinase pada ekstrak kasar ditentukan dengan menginkubasi $0,1 \mathrm{~mL}$ enzim dengan $1 \mathrm{~mL}$ buffer $(0.1$ $\mathrm{M}$ pH 5,0 buffer natrium asetat). Substrat (sebanyak $1 \mathrm{~mL}$ inulin $0,1 \%$ diinkubasi dalam buffer natrium asetat pada suhu $35^{\circ} \mathrm{C}$ selama 10 menit). Kadar gula pereduksi ditentukan dengan metode 3.5dinitrosalisilat (DNS). Satu unit aktivitas enzim inulinase dinyatakan sebagai jumlah enzim yang mengkatalisis terbentuknya $1 \mu \mathrm{mol}$ fruktosa per menit pada $\mathrm{pH} 6.0$ dan suhu $35^{\circ} \mathrm{C}$ (Miller 1959). Beberapa parameter yang menyangkut aktivitas enzim, seperti waktu inkubasi, suhu dan pH optimum dari ekstrak enzim kasar ditentukan, kadar gula pereduksi ditentukan dengan metode NelsonSomogyi dan kadar proteinnya ditentukan dengan metode Lowry (Lowry et al. 1951). Lebih lanjut parameter kinetika seperti konstanta MichaelisMenten $\left(\mathrm{K}_{\mathrm{M}}\right)$ dan laju reaksi maksimum $\left(\mathrm{V}_{\text {maks }}\right)$ dari enzim juga ditentukan.

\section{Fraksionasi Enzim dengan Amonium Sulfat}

Ekstrak enzim kasar difraksionasi pada rentang kejenuhan amonium sulfat (0-20\%, 20-40\%, 40-60\%, 60-80\% dan $80-100 \%$ ). Hasil fraksionasi kemudian disentrifugasi dan endapan yang terbentuk pada setiap tahapan fraksionasi disuspensikan dengan 0,01 $\mathrm{M}$ buffer fosfat $\mathrm{pH} 7$, kemudian ditentukan aktivitas dan kadar proteinnya. Fraksi yang menunjukkan adanya aktivitas enzim inulinase dikumpulkan dan dimurnikan lebih lanjut dengan kromatografi kolom filtrasi gel Sephadex G-25.

\section{Kromatografi Kolom Gel Filtrasi Sephadex G-25}

Fraksi enzim hasil pengendapan dengan amonium sulfat selanjutnya dimurnikan dengan kromatografi kolom filtrasi gel Sephadex G-25 (kolom: $100 \times 2$ $\mathrm{cm})$. Sebagai pengelusi digunakan larutan asam asetat $0,05 \mathrm{M}$, laju alir $5 \mathrm{~mL} / 3$ menit. Sebanyak 65 fraksi (tabung) dikumpulkan dan diukur serapannya pada panjang gelombang $280 \mathrm{~nm}$. Setiap fraksi diukur aktivitasnya dan fraksi-fraksi yang menunjukkan adanya aktivitas inulinase dikumpulkan untuk dimurnikan lebih lanjut dengan kromatografi pertukaran ion DEAE-selulosa.

\section{Kromatografi Kolom Penukar Ion DEAE Selulosa}

Fraksi-fraksi yang menunjukkan adanya aktivitas enzim inulinase dimasukkan ke dalam kolom pertukaran ion DEAE-selulosa (kolom: $20 \times 1,6 \mathrm{~cm}$ ). Sebelum dikromatografi, sampel terlebih dahulu didialisis dalam larutan 0,01 M buffer fosfat $\mathrm{pH} 7,0$ untuk menyetimbangkan dengan buffer pengelusi. Sampel enzim dielusi dengan buffer fosfat $\mathrm{pH} 7,0$ (gradient konsentrasi 0,01-0,1 M), dengan laju alir 1 mL/menit. Fraksi-fraksi hasil kromatografi ditampung (masing-masing $3 \mathrm{~mL} /$ tabung), dikumpulkan dan diukur serapannya pada panjang gelombang $280 \mathrm{~nm}$. Setiap fraksi yang menunjukkan serapan protein ditentukan aktivitas enzimnya. 


\section{Karakterisasi Enzim Inulinase}

Penentuan Suhu, pH dan Waktu Inkubasi Optimum

Proses inkubasi campuran substrat-enzim ditentukan pada rentang $\mathrm{pH} 4,5 ; 5,0 ; 5,5 ; 6,0 ; 6,5$ dan 7,0 (buffer natrium asetat untuk $\mathrm{pH} 4,5-5,5$; buffer fosfat untuk $\mathrm{pH}$ 6,0-7,0), disiapkan untuk menentukan $\mathrm{pH}$ optimum inkubasi dari enzim inulinase pada ekstrak kasar A. flavus. Aktivitas enzim inulinase pada setiap sampel ditentukan dalam satuan $\mathrm{U} / \mathrm{mL}$. Inkubasi dilakukan pada suhu $35^{\circ} \mathrm{C}$ selama 10 menit. Untuk menentukan suhu optimum, uji aktivitas enzim ditentukan pada kondisi $\mathrm{pH}$ optimum yang diperoleh, pada variasi suhu inkubasi $25,30,35,40,45,50,55$, dan $60^{\circ}$ C.Sedangkan untuk memperoleh waktu inkubasi optimum dilakukan penentuan aktivitas enzim pada rentang waktu 1, 2, 3, 4, 5 dan 6 jam, pada $\mathrm{pH}$ dan suhu optimum yang diperoleh (Ertan et al. 2005).

\section{Penentuan Parameter Kinetika Enzim Inulinase}

Unuk penentuan parameter kinetika $\left(\mathrm{K}_{\mathrm{M}}\right.$ dan $\mathrm{V}_{\text {maks }}$ ) dari enzim inulinase A. flavus Gmn11.2. Aktivitas enzim ditentukan dengan menggunakan campuran $0,1 \mathrm{~mL}$ sampel enzim dan substrat (rentang $10,15,20,25 \mathrm{mg} / \mathrm{mL}$ ) inulin. Inkubasi dilakukan pada $\mathrm{pH}$, suhu dan waktu inkubasi optimum enzim. Nilai $\mathrm{K}_{\mathrm{M}}$ dan $\mathrm{V}_{\text {maks }}$ dari enzim inulinase A.flavus Gmn11.2 dihitung menggunakan kurva LineweaverBurk (Sanal et al. 2005).

\section{Penentuan Berat Molekul dengan Elektroforesis SDS-Poliakrilamida}

Setiap fraksi hasil kromatografi yang menunjukkan adanya aktivitas enzim inulinase ditentukan berat molekul-nya $(\mathrm{Mr})$ dengan menggunakan elektroforesis SDS poliakrilamida dengan pewarna komasi biru, indikator/pelacak bromfenol biru. Laju/pergerakan enzim pada lajur elektroforesis dibandingkan dengan marker (protein standar; Mr. 94; 67; 43; 30; dan 20,1 kDa). Penentuan yang sama juga dilakukan untuk sampel ekstrak enzim kasar, sampel hasil fraksionasi amonium sulfat, fraksi hasil kromatografi kolom filtrasi gel Sephadex G-25 dan hasil kromatografi kolom pertukaran anion DEAE-Selulosa.

\section{HASIL DAN PEMBAHASAN}

Isolasi dan Identifikasi Jamur Penghasil Inulinase

Isolat jamur yang diisolasi dari umbi tanaman dahlia yang berasal dari berbagai tempat sentra perkebunan dahlia di pulau Sumatera dan Jawa diperoleh beberapa isolat yang memiliki potensi untuk menghasilkan enzim inulinase dengan aktivitas yang cukup tinggi. Setelah diidentifikasi isolat-isolat jamur yang memiliki potensi untuk menghasilkan enzim inulinase tersebut adalah: isolat jamur $A$. clavatus dari daerah Brastagi, Sumatera Utara (kode BG5; menghasilkan gula pereduksi $2,94 \mathrm{mg} / \mathrm{mL}$ dan fruktosa $0,38 \mathrm{mg} / \mathrm{mL}$ ), isolat jamur Fusarium solani dari daerah Pekanbaru, Sumatera (kode PB3; menghasilkan gula pereduksi 2,30 $\mathrm{mg} / \mathrm{mL}$ dan fruktosa $0,31 \mathrm{mg} / \mathrm{mL}$ ), isolat jamur Fusarium sp2 dari daerah Lembang, Jawa Barat (kode LB2; menghasilkan gula pereduksi $1,76 \mathrm{mg} / \mathrm{mL}$ dan fruktosa $0,25 \mathrm{mg} / \mathrm{mL}$ ), dan isolat jamur A. flavus dari daerah Malang, Jawa Timur (kode ML2; menghasilkan gula pereduksi $1,67 \mathrm{mg} / \mathrm{mL}$ dan fruktosa $0,24 \mathrm{mg} / \mathrm{mL}$ ). Sementara itu, isolat-isolat jamur lainnya memiliki aktivitas penghasil gula pereduksi dan fruktosa yang rendah dan sedang. Untuk selanjutnya, isolat jamur yang memiliki aktivitas inulinase cukup tinggi dikembangbiakkan dan dijadikan sebagi sumber enzim inulinase. Salah satunya isolat jamur A. flavus yang berasal dari Malang (kode ML2) dipilih untuk dikembangbiakan dan diteliti lebih lebih lanjut. Isolat jamur tersebut yang dipilih karena selain memiliki kemampuan untuk memproduksi enzim inulinase dengan aktivitas yang cukup tinggi, juga sudah dilakukan pemuliaan dan dikembangbiakan sebagai galur lokal (A. flavus Gmn11.2).

Populasi jamur dalam media fermentasi ditentukan dalam bentuk berat kering sel. Proses fermentasi dilakukan selama 132 jam dan setiap rentang waktu 12 jam ditentukan berat kering sel, kadar gula pereduksi dan aktivitas enzimnya. Kurva pertumbuhan yang dihasilkan ditunjukkan pada Gambar 1. Hasil analisis menunjukkan bahwa aktivitas enzim inulinase optimum pada jam ke-84 (7 $\times 12$ jam). Kadar gula pereduksi menurun dari jam ke-0 sampai jam ke-84, seiring dengan meningkatnya jumlah sel dan kenaikan aktivitas enzim inulinase. Dari kurva pertumbuhan yang diperoleh disimpulkan bahwa proses produksi enzim inulinase oleh jamur $A$. flavus Gmn11.2 optimum pada jam ke-84.

\section{Fraksionasi Enzim dengan Amonium Sulfat}

Enzim inulinase yang dihasilkan oleh jamur $A$. flavus merupakan enzim ekstraseluler, maka untuk proses isolasi enzim, dimulai dengan proses sentrifugasi medium fermentasi kemudian protein pada supernatannya difraksionasi menggunakan garam amonium sulfat pada berbagai variasi kejenuhan. Protein (enzim) akan mengendap secara selektif tanpa mengalami denaturasi (McPherson 1982). Hasil proses pengendapan protein pada berbagai variasi kejenuhan amonium sulfat ditunjukkan pada Tabel 1.

Fraksi protein yang mengendap pada kejenuhan amonium sulfat $40-60$ dan $60-80 \%$ serta memiliki aktivitas enzim inulinase yang tinggi, dikumpulkan dan dimurnikan lebih lanjut dengan kromatografi kolom filtrasi gel pada matriks Sephadex G-25.

\section{Kromatografi Kolom Filtrasi Gel Sephadex G-25}

Endapan protein hasil fraksionasi yang mengendap pada kejenuhan amonium sulfat $40-80 \%$ dan memiliki aktivitas enzim inulinase dilarutkan dalam buffer fosfat $0,01 \mathrm{M} \mathrm{pH} 7,0$, kemudian dimasukkan ke dalam kolom Sephadex G-25. 


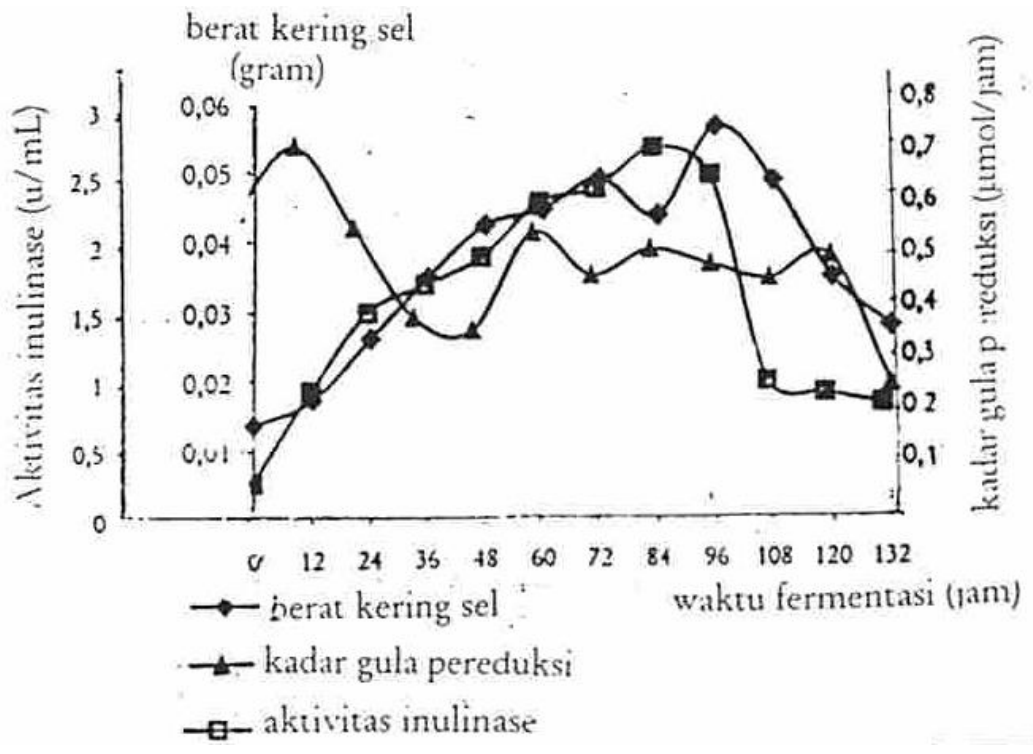

Gambar 1. Kurva pertumbuhan jamur A. flavus pada medium fermentasi, yang dinyatakan dengan berat kering sel. Proses fermentasi dilakukan selama 7 hari pada suhu $30^{\circ} \mathrm{C}$ dan setiap 12 jam diambil contoh sebanyak 10 $\mathrm{mL}$ untuk ditentukan populasi jamur, aktivitas inulinase, kadar protein dan kadar gula pereduksinya. Proses produksi enzim inulinase oleh jamur A. flavus Gmn11.2 optimum pada jam ke-84.

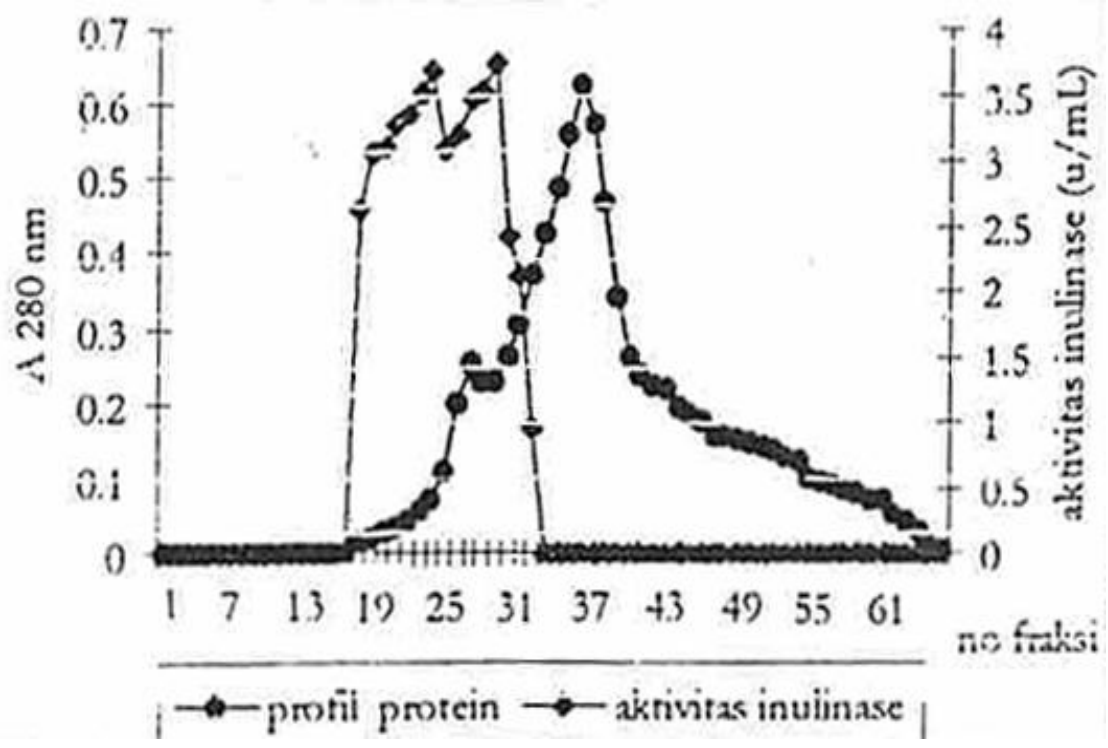

Gambar 2. Hasil kromatografi kolom filtrasi gel Sephadex G-25 $(100 \times 2 \mathrm{~cm})$ dari sampel protein yang mengendap pada kejenuhan amonium sulfat $40-80 \%$. Larutan pengelusi asam asetat $0,05 \mathrm{M}$, laju alir $5 \mathrm{~mL} / 3$ menit. Serapan tiap fraksi diukur pada panjang gelombang $280 \mathrm{~nm}$. Aktivitas enzim inulinase ditentukan terhadap substrat inulin dan penentuan kadar protein dengan metode Lowry.

Tabel 1. Proses fraksionasi/pengendapan enzim inulinase dengan berbagai variasi kejenuhan amonium sulfat (020, 20-40, 40-60, 60-80, dan 80-100\%). Aktivitas enzim inulinase terakumulasi pada kejenuhan amonium sulfat 40-60 dan 60-80\%.

\begin{tabular}{ccc}
\hline $\begin{array}{c}\text { Fraksi } \\
(\%)\end{array}$ & $\begin{array}{c}\text { Aktivitas Total } \\
\text { (Unit) }\end{array}$ & Distribusi (\%) \\
\hline $0-20$ & 0,64 & 0,88 \\
$20-40$ & 0,56 & 0,77 \\
$40-60$ & 34,30 & 46,98 \\
$60-80$ & 36,50 & 50,00 \\
$80-100$ & 1,00 & 1,37 \\
\hline
\end{tabular}


Pengelusi yang digunakan adalah asam asetat $0,05 \mathrm{M}$, dengan laju alir $5 \mathrm{~mL} / 3$ menit. Setiap fraksi yang keluar dari kolom ditampung dengan volume 5 $\mathrm{mL} /$ tabung. Serapan dari setiap fraksi diukur pada panjang gelombang $280 \mathrm{~nm}$ dan aktivitas enzim inulinase ditentukan terhadap substrat inulin. Kadar protein tiap fraksi ditentukan dengan metode Lowry. Hasil kromatografi kolom filtrasi gel Sephadex G-25 ditunjukkan pada Gambar 2.

Hasil kromatografi filtrasi gel Sephadex G-25 (Gambar 2) menunjukkan adanya dua puncak protein, dimana aktivitas enzim inulinase berada pada fraksi 17-31, sedangkan pada fraksi 32-43 meskipun kadar proteinnya cukup tinggi tapi fraksi-fraksi tersebut tidak memiliki aktivitas enzim inulinase. Maka untuk tahapan pemurnian selanjutnya diambil fraksi 17-31, untuk dimurnikan dengan kromatografi kolom penukar anion DEAE-selulosa.

Kromatografi Kolom Penukar Ion DEAE Selulosa

Fraksi-fraksi hasil kromatografi filtrasi gel Sephadex G-25 yang memiliki aktivitas enzim inulinase (fraksi 17-31), selanjutnya dimurnikan dengan kromatografi kolom penukar anion pada matriks DEAE-selulosa. Kromatogram hasil pemurnian ditunjukkan pada Gambar 3. Hasil pemurnian dengan kromatografi penukar anion DEAE-selulosa menunjukkan bahwa fraksi-fraksi yang memilki aktivitas enzim inulinase adalah fraksi nomor 29-33, pada puncak protein yang kedua, fraksi tersebut terelusi dari matriks DEAE-selulosa pada konduktivitas 2,9-4,8 mMho. Untuk mengetahui kemurnian dan berat molekul (Mr) dari fraksi protein 29-33 tersebut dikarakterisasi dengan elektroforesis SDS-poliakrilamida.

\section{Karakterisasi Enzim Inulinase}

Penentuan pH, Suhu dan Waktu Inkubasi Optimum

Penentuan $\mathrm{pH}$ optimum dilakukan pada suhu $35^{\circ} \mathrm{C}$, waktu inkubasi 5 jam pada rentang $\mathrm{pH}$ 4,5-7,0. Hasilnya menunjukkan bahwa aktivitas enzim tertinggi dihasilkan pada $\mathrm{pH}$ 5,0. Hasil tersebut mirip dengan $\mathrm{pH}$ optimum dari enzim inulinase yang berasal dari jamur Aspergillus sp yang dihasilkan oleh Vandamme \& Deryke (1983), memiliki aktivitas tertinggi pada rentang $\mathrm{pH} 4,5-5,0$. Penentuan suhu optimum enzim dilakukan pada $\mathrm{pH}$ 5,0; waktu inkubasi 5 jam dengan variasi suhu $30-60^{\circ} \mathrm{C}$, hasilnya menunjukkan bahwa aktivitas enzim tertinggi dicapai pada suhu $50^{\circ} \mathrm{C}$. Hasil tersebut mirip dengan aktivitas enzim inulinase yang berasal dari jamur Kluyvermyces marxianus memiliki suhu optimum $50^{\circ} \mathrm{C}$ (Vandamme \& Derycke 1983). Untuk penentuan waktu inkubasi optimum dilakukan pada kondisi $\mathrm{pH}$ dan suhu optimum pada rentang 1-6 jam. Hasil penentuan diperoleh aktivitas tertinggi enzim pada waktu inkubasi 4 jam. Dengan demikian enzim inulinase dari A. flavus Gmn11.2 galur lokal, memiliki aktivitas tertinggi pada $\mathrm{pH} 5,0$, suhu $50^{\circ} \mathrm{C}$ dan waktu inkubasi 4 jam. Hasil penelitian lain yang

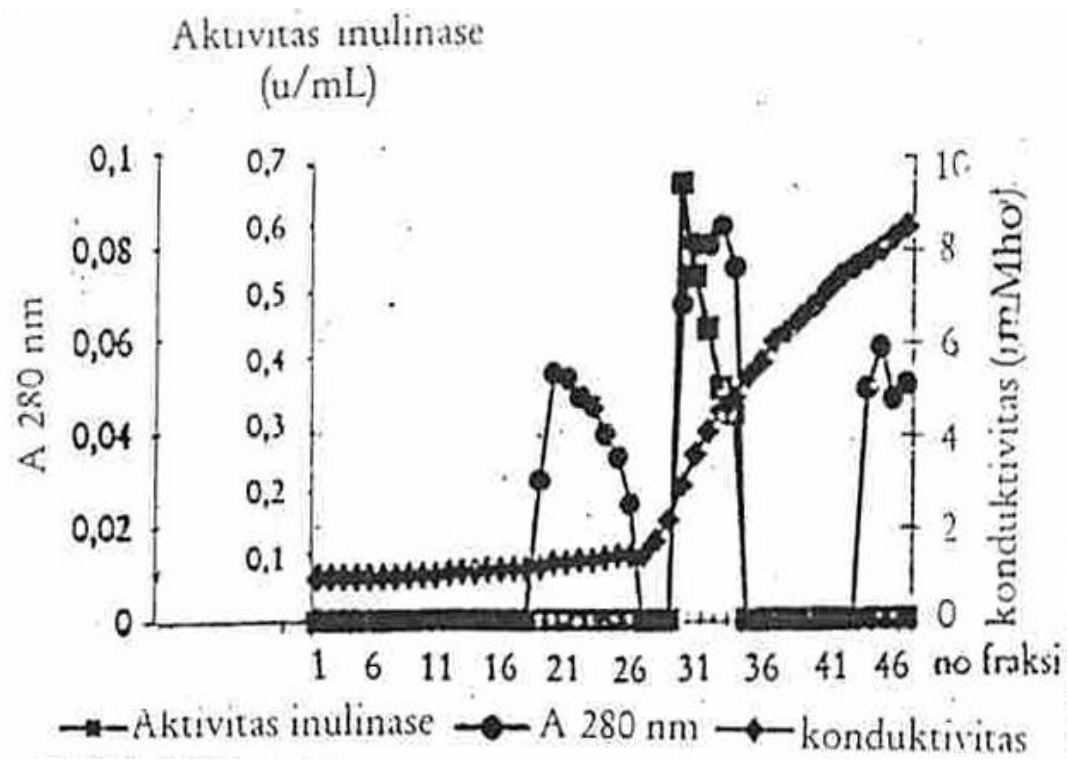

Gambar 3. Hasil kromatografi kolom penukar anion DEAE-selulosa $(20 \times 1,6 \mathrm{~cm})$. Sampel dari fraksi filtrasi gel Sephadex G-25 yang memiliki aktivitas enzim inulinase (fraksi 17-31 \}. Larutan pengelusi buffer fosfat $\mathrm{pH}$ 7,0 (gradient konsentrasi 0,01-0,1 M), dengan laju alir $1 \mathrm{~mL} / \mathrm{menit}$. Volume fraksi $3 \mathrm{~mL} / \mathrm{tabung}$.Serapan tiap fraksi diukur pada panjang gelombang $280 \mathrm{~nm}$. Aktivitas enzim inulinase ditentukan terhadap substrat inulin dan penentuan kadar protein dengan metode Lowry. Untuk memonitor kenaikan konsentrasi buffer (elusi gradien), ditentukan konduktivitanya dengan konduktivitimeter. Fraksi protein yang memiliki aktivitas enzim inulinase yaitu fraksi 29-33. 
dilaporkan oleh Karaktop \& Sanal (2015), menunjukkan bahwa enzim inulinase yang diisolasi dari jamur Aspergillus wentii memiliki aktivitas optimum pada $\mathrm{pH} 6,5$; suhu $35^{\circ} \mathrm{C}$, waktu inkubasi 10 menit. Sementara itu, hasil penelitian Laowklom et al. (2012) menunjukkan enzim inulinase yang diisolasi dari isolat Sterptomyces spp. CP01, memiliki aktivitas optimum pada $\mathrm{pH} 6,0$; suhu $55^{\circ} \mathrm{C}$.

\section{Penentuan Parameter Kinetika Enzim Inulinase}

Untuk penentuan parameter kinetika $\left(\mathrm{K}_{\mathrm{M}}\right.$ dan Vmaks) dari enzim inulinase A. flavus Gmn11.2. Aktivitas enzim ditentukan dengan menggunakan campuran $0,1 \mathrm{~mL}$ sampel enzim dan substrat inulin (rentang 10, 15, 20, $25 \mathrm{mg} / \mathrm{mL}$ ). Inkubasi dilakukan pada $\mathrm{pH} 5,0$, suhu $50^{\circ} \mathrm{C}$ dan waktu inkubasi 4 jam. Nilai $\mathrm{K}_{\mathrm{M}}$ dan $\mathrm{V}_{\text {maks }}$ dari enzim inulinase A. flavus Gmn11.2 dihitung menggunakan kurva LineweaverBurk (Sanal et al. 2005). Hasil analisis menunjukkan $\mathrm{K}_{\mathrm{M}}$ dan $\mathrm{V}_{\text {maks }}$ dari enzim inulinase A. flavus Gmn11.2 adalah $32,4 \mathrm{mg} / \mathrm{mL}$ dan $1,8 \times 10^{-3} \mu \mathrm{mol} / \mathrm{menit}$.

Bila dibandingkan dengan harga $\mathrm{K}_{\mathrm{M}}$ dari enzim inulinase yang berasal dari jamur Aspergillus ficuum hasil penelitian Carniti et al. (1991), yaitu sebesar $24,1 \mathrm{mg} / \mathrm{mL}$, hal ini menunjukkan harga $\mathrm{K}_{\mathrm{M}}$ yang tidak jauh berbeda. Namun tentunya, semakin kecil harga $\mathrm{K}_{\mathrm{M}-\text { nya makin tinggi afinitasnya terhadap }}$ substrat inulin.

\section{Penentuan Berat Molekul Enzim dengan} Elekroforesis SDS-Poliakrilamida

Untuk mengetahui berat molekul (Mr) enzim inulinase dari A. flavus Gmn11.2 galur lokal hasil pemurnian, ditentukan dengan elektroforesis SDSpoliakrilamida. Mobilitas enzim dibandingan dengan mobilitas protein standar (marker; dengan variasi $\mathrm{Mr}$ 94; 67; 43; 30 dan 20,1 kDa).

Dari hasil elektroforesis SDS-poliakrilamida menunjukkan banyaknya protein yang terdapat pada fraksi protein. Dimulai dari ekstrak enzim kasar, hasil fraksionasi dengan amonium sulfat, hasil kromatografi kolom filtrasi gel dan kromatografi kolom penukar anion, enzim inulinase dari A. flavus Gmn11.2 belum terpisahkan secara baik. Dalam hal ini masih kelihatan banyaknya protein pengotor lainnya (Gambar 4). Namun setelah fraksi yang memiliki aktivitas enzim inulinase dari hasil kromatografi kolom filtrasi gel Sephadex G-25, dimurnikan lebih lanjut dengan kromatografi kolom penukar anion DEAE-selulosa, menghasilkan dua puncak protein. Fraksi protein yang memiliki aktivitas enzim inulinase yaitu fraksi 29-33 (Gambar 3), Fraksi protein tersebut selanjutnya ditentukan berat molekulnya dengan elektroforesis SDSpoliakrilamida.

Setelah fraksi fraksi protein yang memiliki aktivitas enzim inulinase, dari hasil kromatografi kolom penukar anion DEAE-selulosa ditentukan berat molekulnya dengan elektroforesis SDSpoliakrilamida, memperoleh hasil seperti yang ditunjukkan pada Gambar 5. Dari elektroforegram yang dihaslkan ternyata mulai dari fraksi 29, 30, 31, 29, 30, 31, 32 dan 33 menunjukkan pita yang sama. Terdapat dua pita utama dengan berat molekul (Mr) masing-masing 72 dan $66 \mathrm{kDa}$ (Gambar 5), yang megidentifkasikan bahwa enzim inulinase dari $A$. flavus Gmn11.2 galur lokal yang diisolasi mengandung dua sub unit polipeptida. Dengan demikian berat molekul (Mr) dari enzim inulinase $A$. flavus Gmn11.2 galur lokal adalah $138 \mathrm{kDa}$.

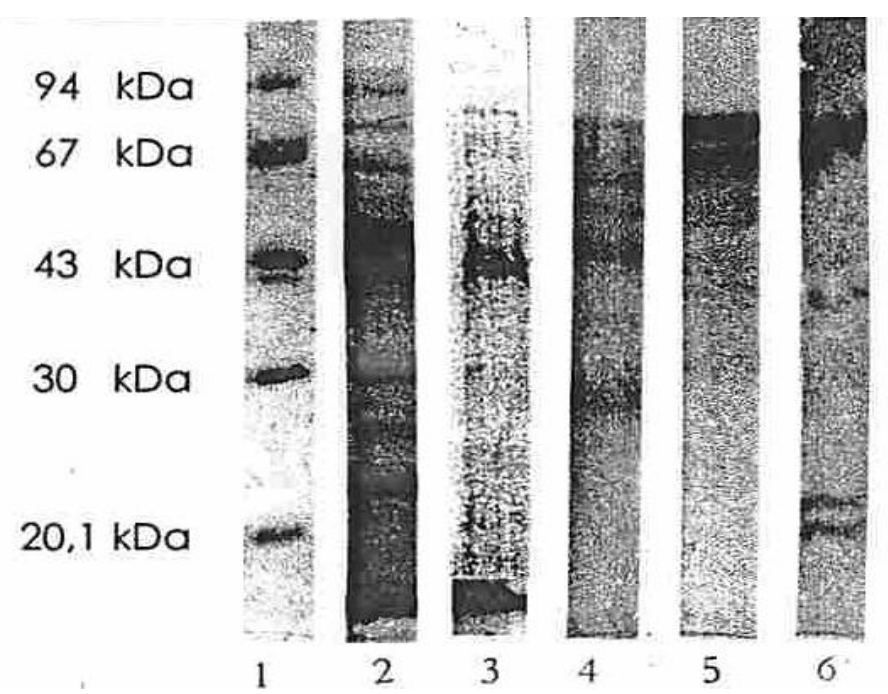

Gambar 4. Hasil elektroforesis SDS-poliakrilamida dari setiap tahapan pemurnian. Lajur 1 Protein standar (marker), Lajur 2 Ekstrak enzim kasar, Lajur 3 Hasil fraksionasi rentang kejenuhan ammonium sulfat 40-80\%, Lajur 4 Fraksi 17-19 hasil kromatografi kolom filtrasi gel Sephadex G-25, Lajur 5 Fraksi 20-25 hasil kromatografi kolom filtrasi gel Sephadex G-25, Lajur 6 Fraksi 26-31 hasil kromatografi kolom filtrasi gel Sephadex G-25. 


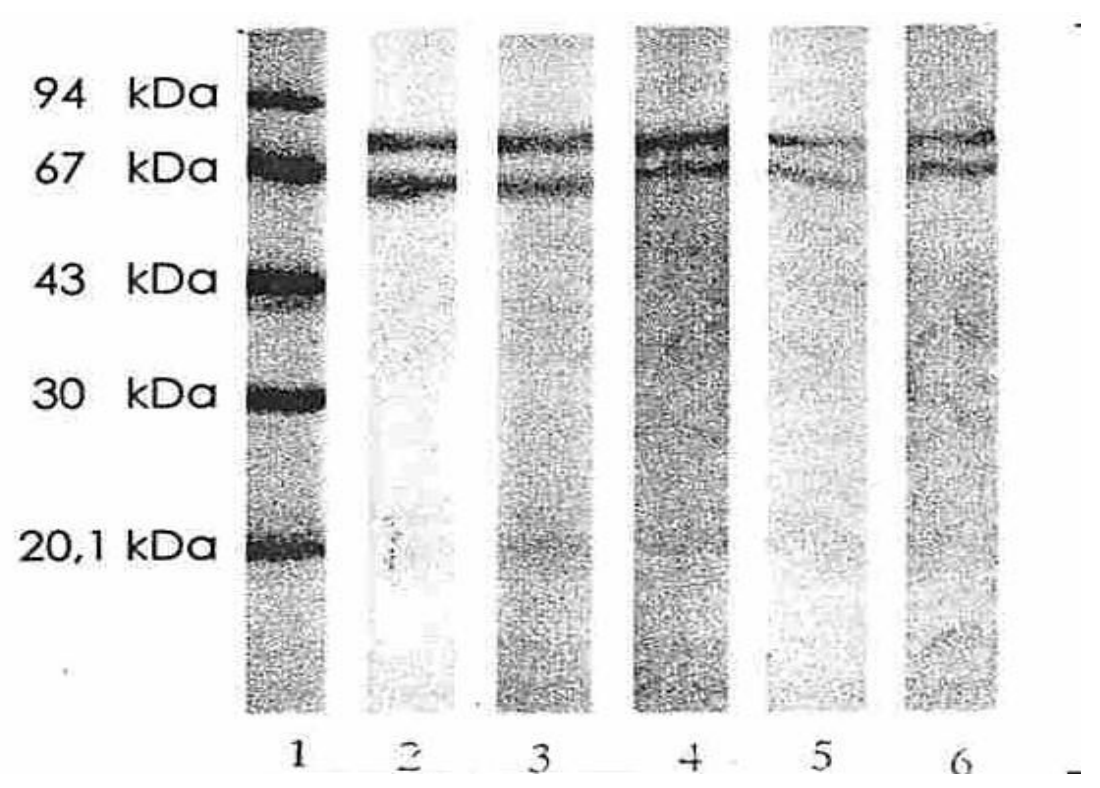

Gambar 5. Hasil elektroforesis SDS-poliakrilamida dari setiap tahapan pemurnian. Lajur 1 Protein standar (marker), Lajur 2 Fraksi 29 hasil kromatografi kolom Penukar ion DEAE-selulosa, Lajur 3 Fraksi 30 hasil kromatografi kolom Penukar ion DEAE-selulosa, Lajur 4 Fraksi 31 hasil kromatografi kolom Penukar ion DEAE-selulosa, Lajur 5 Fraksi 32 hasil kromatografi kolom Penukar ion DEAE-selulosa, Lajur 6 Fraksi 33 hasil kromatografi kolom Penukar ion DEAE-selulosa.

Aktivitas enzim inulinase yang dilaporkan dan dikarakterisasi dari jamur lain yaitu dari Panaeolus papillonaceus, merupakan kelas Basidiomycete pertama yang memiliki aktivitas inulinase telah dimurnikan oleh Mukherje \& Sengupta (1987). Enzim yang diperoleh ternyata juga memiliki dua sub-unit polipeptida dengan total berat molekul (Mr) $116 \mathrm{kDa}$. Enzim yang diisolasi memiliki aktivitas yang lebih tinggi terhadap substrat sukrosa dibandingkan terhadap rafinosa. Aktivitas hidrolitik inulinase juga telah dihasilkan dari Penicilium spp lain yang juga menunjukkan variabilitas yang sama dengan karakteristik enzim inulinase lainnya. Enzim inulinase yang dimurnikan dari kultur jamur $P$. trzebinsk, memiliki dua sub-unit polipeptida dengan berat molekul (Mr) masing-masing 81 dan $87 \mathrm{kDa}$, dimana enzim yang diisolasi menunjukkan aktivitas ekso-inulinase (Onodera \& Shiomi, 1992). Peneliti lainnya melaporkan inulinase dari Penicillium sp. $\mathrm{TN}-88$, yang juga memproduksi suatu endo-acting inulinase, memiliki berat molekul $68 \mathrm{kDa}$ (Nakamura et al. 1997). Jenis ekso-enzim inulinase yang dimurnikan dari ekstrak ekstraseluler jamur $P$. janczewskii, yang dilaporkan oleh Pessoni et al. (1999), memiliki dua sub-unit polipeptida, dengan berat molekul (Mr) masing-masing 48 dan $66 \mathrm{kDa}$. Hasil penelitian lain yang dilaporkan oleh Laowklom et al. (2012), menunjukkan enzim inulinase yang diisolasi dari isolat Sterptomyces spp. CP01, memiliki satu sub-unit polipeptida tunggal, dengan aktivitas enzimatik optimum pada $\mathrm{pH} 6,0$; suhu $55^{\circ} \mathrm{C}$ (Laowklom et al. 2012).

\section{KESIMPULAN}

Hasil Penelitian menunjukkan bahwa dari berbagai mikroorganisme yang memiliki potensi untuk menghasilkan enzim inulinase dengan aktivitas yang tinggi adalah $A$. clavatus (kode BG5), $A$. clavatus (kode PB3), Fusarium sp2 (kode LB2), dan A. flavus (kode ML2).

Setelah melalui tahapan kromatografi penukar ion, diperoleh enzim inulinase yang cukup murni yang ditandai dengan intensitas pita hasil SDS elektroforesis, dengan peningkatan faktor kemurnian 15,66 kali dibandingkan dengan ekstrak enzim kasar.

Aktivitas enzim inulinase hasil isolasi dari $A$. flavus Gmn11.2 galur lokal, bekerja pada kondisi optimum: suhu $50^{\circ} \mathrm{C}, \mathrm{pH} 5,0$ dan waktu inkubasi 4 jam.

Parameter kinetika enzimatik dari inulinase diperoleh harga $\mathrm{K}_{\mathrm{M}} 33 \mathrm{mg} / \mathrm{L}$ dan $\mathrm{V}_{\text {maks }} 1,8 \times 10^{-3}$ $\mu \mathrm{mol} / \mathrm{menit}$. Hasil elektroforesis SDS poliakrilamida menunjukkan enzim inulinase dari A. flavus Gmn11.2 galur lokal, memiliki berat molekul (Mr) $138 \mathrm{kDa}$, terdiri dari dua sub-unit polipeptida (dimer) dengan Mr masing-masing 72 dan $66 \mathrm{kDa}$.

\section{DAFTAR PUSTAKA}

Allais, J.J., Hoyos-Lopez, G., Kammoun, S. \& Barrati, J.C. (1987). Isolation and characterization of thermophilic bacterial strain with inulinase activity. Applied and Environmental Microbiology. 53(5): 942-945.

Allais, J.J., Kammoun, S., Blanc, P., Birrad, C. \& Barrati, J.,C. (1986). Isolation and Characterization of bacteria strain with 
inulinase activity. Applied and Environmental Microbiology. 52: 1086-1090.

Baron, M., Florencio, J.A., Zanin, G.M., Ferreira, G., Ernes, R. \& Fontana, J.D. (1996). Difructose anhydride-forming bacterial inulinase II and fructogenic fungal inulinase I- Free and immobilized form. Applied Biochemistry and Biotechnology. 57(8): 605-615.

Belmari, M., Sassi, A.H., Savart, M., Tantauielaraki, A. \& Cottin, P. (1994). Purification and property of an inulinase-like $\beta$-fructosidase from Bacillus stearothermophylus. Letters in Applied Microbiology. 19(6): 410-413.

Bume, R., Wen, Z.T., Chen, Y.M. \& Penders, J.E. (1999). Regulation of expression of the fructan hydrolase gene of Streptococcus mutan GS-5 by induction and carbon catabolite repression. Journal of Bacteriology. 181(9): 2863-2871.

Carniti, P., Beltrame, P.L., Gurdione, D., Focher, B. \& Marzeti, A. (1991). Hydrolisis of inulin: a kinetic study of the reaction catalized by an inulinase from Aspergillus ficuum. Biotehnology and Bioengineering. 37: 575-579.

Chung, B.H., Kim, B.M. \& Nam, S.W. (1996). The use of inulinase pre-pro leader peptide in Saccharomyces cerevisiae. Biotechnology Letters. 18(6): 627-632.

Cruzguerrero, A., Garciapena, I., Barzona, E., Garciagaribay, M. \& Gomezruiz, L. (1995). Kluyveromyces marxianus CDBB-L-278: A wild inulinase hyperproducing strains. Journal of Fermentation and Bioengineering. 80(2): 159-163.

Ertan, F., Sanal, E. F., Kaboğlu, Ç. A., Aktaç, T.\& Bakar, E. (2005). Some properties of inulinase from Rhizoctonia solani. Journal of Biological Science. 5(3): 330-334.

Flemming, S.E. \& Grootwassing, J.W.D. (1979). Preparation of High Fructose Syrup from the tuber of Jerusalem artichoke (Halianthus tuberosus L.). Critical Reviews in Food Science and Nutrition. 12: 1-28.

Guiraud, J.P. \& Galzy, P., 1990. Inulin conversion by yeasts. Yeast: Biotechnology and Biocatalysis. 255-296.

Gupta, A.K., Kaur, M., Kaur, N. \& Singh, R. (1992). A comparison of properties of inulinases of Fusarium oxysporum immobilised on various supports. Journal of Chemical Technology and Biotechnology. 53(3): 293-296.

Gupta, A.K., Rathore, P., Kaur, N. \& Singh, R. (1990). Production thermal stability and immobilization of inulinase from Fusarium oxysporum. Journal of Chemical Technology and Biotechnology. 45(1): 245-251.

Kango, N. \& Jain, S.C. (2011). Production and properties of microbial inulinases: Recent advances. Food Biotechology. 25: 165-212.

Karatop, R. \& Sanal, F. (2015). Preliminary characterization of crude inulinase activity of
Aspergillus wentii. Trakya University Journal of Natural Sciences. 16(1): 25-30.

Kaur, N., Kaur, M., Gupta, A.K. \& Singh, R. (1992). Properties of $\beta$-fructosidases (invertase and inulinase) of Fusarium oxysporum grown on an aqueous extract of Cichorium intybus roots. Journal of Chemical Technology and Biotechnology. 53: 279-284.

Kıran, Ö.E., Çömlekçioğlu, U. \& Dostbil, N., (2006). Mikrobiyal Enzimler ve Endüstride Kullanım Alanlar1. Kahramanmaraş Sütçüimam Üniversitesi Fen ve Mühendislik Dergisi. 9(1): 12-19.

Laowklom, N., Chantanaphan, R. \& Pinphanichakarn, P. (2012). Production, purification and characterization of inulinase from a newly isolated Streptomyces sp. CP01. Natural Resources. 3: 137-144.

Levi, B. \& Werman, M.J. (1998). Long-term fructose consumption accelerates glycosylation and several age-related variabilitis in male rats. Journal of Nutrition. 128: 1442-1449.

Lowry, O.H., Rosebrough, N.J., Farr, A.L. \& Randall, R.J. (1951). Protein measurement with the Folin phenol reagent. Journal of Biological Chemistry. 193(1): 267-275.

Miller, G.L. (1959). Use of dinitrosalicylic acid reagent for determination of reducing sugars. Analytical Chemistry. 31(3): 426-428.

Mukherjee, K. \& Sengupta, S. (1987). Purification and properties of a non-specific fructofuranosidase (inulinase) from the mushroom Panaeolus papillonaceus. Canadian Journal of Microbiology. 33: 520-524.

Nakamura, T., Shitara, A., Matsuda, S., Matsuo, T., Suiko, M. \& Ohta, K. (1997). Production, purification and properties of an endo-inulinase from Penicillium sp. TN-88. Journal of Fermentation and Bioengineering. 84: 313318.

Onodera, S. \& Shiomi, N. (1992). Purification and subsite affinities of exoinulinase from Penicillium trzebinskii. Bioscience, Biotechnology and Biochemistry. 56: 14431447.

Pessoni, R.A.B., Figueiredo, R. \& Braga, M.R. (1999). Extracellular inulinases from Penicillium janczewskii, a fungus isolated from rhizosphere of Vernonia herbacea (Asteraceae). Jornal of Applied Microbiology. 87: 141-147.

Prosky, L. \& Hoebregs, H. (1999). Method to determine food inulin and oligo-fructose. Journal of Nutrition. 129: 1418S-1423S.

Roberfroid, M.B. \& Dezelne, N.M. (1998). Dietary fiber. Annual Review of Nutrition. 18: 117-142.

Sanal E, F., Ertan, F. \& Aktac, T. (2005). Production of Exoinulinase from Alternaria alternata growth on Jerusalem artichoke and some biochemical properties. Journal of Biological Science. 5(4): 497-505. 
Singh, P. \& Gill, P.K. (2006). Production of Inulinases. Food Technology and Biotechnology. 44(2): 151-162.

Smith, J.E. (1997). Biotechnology, Studies in Biology. Third ed. Cambridge University Pres. Cambridge.

Suhartono, M.T. (1989). Enzim dan Bioteknologi. Pusat Antar Universitas. Institut Pertanian Bogor. Bogor.
Vandamme, E.J. \& Derycke, D.G. (1983). Microbial inulinase: Fermentation process, properties and application. Advances in Applied Microbiology. 29: 139-176.

Visnawathan, P. \& Kulkarni, P.R. (1995). Properties and application of inulinase obtained by fermentation of Costus (Saussurea lappa) root powder with Aspergillus niger. Nahrung-Food. 39(4): 288-294. 